\title{
Tomasz Maliszewski, Małgorzata Rosalska (red.), Uniwersytety ludowe. Pomiędzy starymi a nowymi wyzwaniami, Wydawnictwo Adam Marszałek, Toruń 2016, ss. 408
}

\begin{abstract}
Kultura ludowa nie opisuje jakiegoś spójnego systemu czy zunifikowanej mentalności, lecz zespół praktyk, gestów i rytuałów, mogące zmienić się z biegiem czasu, różnić się w zależności od środowiska, a niekiedy pozostawać ze sobą w sprzeczności.
\end{abstract}

(Schindler, 2002, s. 6)

\section{Wstęp}

Pierwszą myślą, jaka pojawiła się podczas czytania recenzowanej monografii Uniwersytety ludowe. Pomiędzy starymi a nowymi wyzwaniami pod redakcją naukową Tomasza Maliszewskiego i Małgorzaty Rosalskiej, była myśl o ciągle trwającym wykluczaniu i selekcji społecznej, którymi na gruncie polskich nauk humanistycznych i społecznych zajmują się/zajmowali się m.in. Zbigniew Kwieciński (m.in. Wykluczanie, 2002; Nieuniknione? Funkcje alfabetyzacji w dorosłości, 2002 czy Bezbronni. Odpad szkolny na wsi, 2002), jak również Ryszard Borowicz (patrz m.in. Nierówności społeczne w dostępie do wykształcenia. Casus Suwalszczyzny, 2000; Procesy selekcji w szkole wyższej, 1978). To właśnie w tym kontekście wykluczania i selekcji odczytywałem recenzowany tekst.

Z jednej strony widzimy i to notabene trwa od wielu lat, że „Polityka oświatowa państwa wyznacza najogólniejsze ramy procesów selekcyjnych w szkolnictwie. Już pierwsi badacze tych problemów w Polsce - J. S. Bystroń, S. Rychliński - zwrócili uwagę na zewnętrze uwarunkowania selekcji dokonywanej w instytucjach kształcenia. Uwarunkowania te, znajdujące swoje odzwierciedlenie w funkcjonowaniu szkolnictwa, to jego związki ze społeczeństwem" (Borowicz1 983 s. 26). Z drugiej przyznajemy rację Lucjanowi 
Turosowi, który w książce Andragogika ogólna napisał „Kształcenie ustawiczne jest ludzką regionalną odpowiedzią na przemianę form i treści życia społecznego, cywilizacji i kultury [...] Celem kształcenia ustawicznego (permanentnego, ciągłego, nieustającego) jest przygotowanie dorosłych do nadążania za rozwojem cywilizacji, kultury i życia społecznego wiąże się ściśle z pełnieniem przez dorosłych społecznych, zawodowych i rodzinnych ról umożliwia im lepsze, bardziej naukowe rozumienie i doskonalsze realizowanie from i treści życia gospodarczego, ze zmieniającym się rynkiem pracy, z potrzebą zapewnienia sobie optymalnych warunków egzystencji” (Turos 2004, s. 53) Jednak idąc myślą za Jürgenem Habermasem, „Trudno jednak odnaleźć siebie kiedy Nowoczesny, w pełni zracjonalizowany świat jest odczarowany tylko pozornie; spoczywa na nim przekleństwo, demonicznego urzeczowienia i śmiertelnej izolacji. W paraliżu jałowej emancypacji wyraża się zemsta pierwotnych mocy na tych, którzy musieli się wyemancypować, a jednak nie mogli ujść cało. Przymus racjonalnego pokonywania wdzierających się z zewnątrz siły natury narzucił człowiekowi proces kształcenia, który bez miary potęguje siły wytwórcze służące samozachowaniu, ale pozwala zmarnieć siłom pojednania, które wykraczają poza gołe samozachowanie. Panowanie nad zobiektywizowaną zewnętrzną i represjonowaną wewnętrzną naturą jest trwałym znakiem oświecenia" (Habermas 2000, s. 131).

Odczuwając z jednej strony konieczność robienia czegoś, chociażby dawania szansy na zdobycie wiedzy, a z drugiej poczucie zapętlenia aksjologicznego we współczesności, autorzy monografii widzą szansę poprzez dogłębną analizę przeszłości, teraźniejszości i przyszłości uniwersytetu ludowego na budzenie potrzeby kształcenia. Recenzowana publikacja jest udaną próbą dokumentacji recepcji założeń społecznych i oświatowych Mikołaja Frederika Severina Grundtviga i jego skandynawskich następców w polskiej myśli pedagogicznej oraz prezentacji kluczowych kierunków praktycznej realizacji idei uniwersytetu ludowego w naszym kraju. Całość jest przeniknięta myślą Jana Amosa Komeńskiego, który w Wielkiej dydaktyce napisał, że „Do szkół należy ściągać nie tylko bogaczy i dostojników, ale wszystkie na równi: szlachetne urodzone i niskiego pochodzenia, bogate i ubogie, chłopców i dziewczęta, z miast i miasteczek, osiedli i wsi” (Komeński 1956, s. 71-72).

Treść monografii została podzielona na pięć odrębnych części, na które składa się wstęp Tomasza Maliszewskiego i Małgorzaty Rosalskiej i 20 autorskich tekstów ukazanych w szerokiej perspektywie, ponieważ mamy tu teksty historyków oświaty, teoretyków wychowania, socjologów, pedagogów praktyków, jak również działaczy oświatowych. 


\section{Wątki wprowadzające - budowanie struktur myślowych}

Pierwszą z nich stanowią trzy rozdziały, które szeroko wprowadzają czytelnika w problematykę Uniwersytetów Ludowych. Tadeusz Aleksander w tekście pt. Uniwersytety ludowe następstwem ruchu przebudowy społeczno-gospodarczej wsi rozpoczął od zarysowania szerokiego tła społecznego w czasach ich początków, kiedy to miały stanowić wielki edukacyjny projekt modernizacyjny adresowany do mieszkańców XIX-wiecznej wsi, konkluduje istotnym pytaniem, czy widoczny powrót do agraryzmu pociągnie za sobą wzrost zainteresowania odbudową ruchu uniwersytetów ludowych w naszym kraju. Tekst Aleksandra zmusza do pytania, czy agraryzm bez możliwości autonomii i samodecydowania nie jest ideologiczną „wydmuszką" dla zaspokojenia politycznych aspiracji. Przecież wystarczy chcieć zobaczyć, że „W uniwersytetach ludowych mogłyby znaleźć wyraźniejsze miejsce zakotwiczenia, a w ich wychowankach - wyraźne wsparcie personalne i merytoryczne" (s. 28). Wiesław Jamrożek natomiast podjął się próby ukazania miejsca uniwersytetów ludowych w edukacji poszkolnej młodzieży wiejskiej w Polsce w okresie międzywojennym, gdzie czytamy, że „Ruch uniwersytetów ludowych w Polsce międzywojennej był istotnym ogniwem szeroko rozumianej oświaty pozaszkolnej" (s. 39). To właśnie ów ruch pielęgnował ideę wspólnotowości jako ważny aspekt wychowawczy. Ostatnim tekstem w tej części jest artykuł Krzysztofa Pierścieniaka, zapraszający do poszukiwań współczesnego modelu uczenia się w uniwersytecie ludowym. Ukazuje, że „pomimo zachodzących zmian, nadal można przyjąć, że edukacja w uniwersytecie ludowym stanowi gwarancję jakości transmisji z pokolenia na pokolenie, określanych wartości i wzorów zachować, istotnych zwłaszcza dla lokalnej społeczności" (s. 75).

\section{W kręgu katolickich uniwersytetów ludowych, czyli o lokalnych wspólnotach wiary i nauki}

Druga część poświęcona została nieco zaniedbanemu w polskim piśmiennictwie pedagogicznym obszarowi badań - katolickim uniwersytetom ludowym. Maliszewski, otwierając tę część, pisze, że „Niestety nasza współczesna wiedza o funkcjonowaniu katolickich uniwersytetach ludowych w okresie międzywojennym jest dalece niepełna" (s. 80). Ukazując ich niezaprzeczalną wartość, skłania tym samym do refleksji, dlaczego nawet we współczesnych czasach deprecjonuje się całożyciowe kształcenie na wsiach, które przejawia się w likwidacji coraz większej liczby szkół czy bibliotek. Zdzisław Machu- 
ra z perspektywy badacza biografii życia ukazuje czytelnikowi nietuzinkową postać i działalności ks. Jana Ziei na Pomorzu Środkowym w drugiej połowie lat 40. XX wieku. Zdzisław Mierzwa i Joanna Truszkowska w swoim tekście dokonali charakterystyki pracy i oceny dorobku Ludowego Uniwersytetu Katolickiego Archidiecezji Przemyskiej w początkach XXI wieku. Ich uwaga została skupiona na „szansach i możliwościach, jakie stwarza uniwersytet ludowy w rozwoju społeczno-kulturowym mieszkańców konkretnego środowiska [...] traktowanego jako studium przypadku" (s. 115). Natomiast Agnieszka Jaworska przedstawiła środowiska i działania katolickich uniwersytetów ludowych w latach 1989-2002 i z przedstawionego tekstu wynika, że „...katolickie uniwersytety ludowe, dynamicznie rozwijające się w Polsce w latach 90. XX w., w pierwszej połowie lat 2000, w większości diecezji przestały istnieć. $W$ wielu zaobserwowano, po zrealizowaniu 3-letniego programu kształcenia, zmniejszenie się liczby słuchaczy i ograniczenie zajęć dydaktycznych” (s. 146). Autorka stawia tezę, że jedną z przyczyn „jest społeczne wyczerpanie zapotrzebowania na ten typ kształcenia, które nie daje kwalifikacji formalnych" (s. 146). Warto jednak pamiętać o wzroście zainteresowania uniwersytetami trzeciego wieku, które również w większości nie dają formalnego wykształcenia. Zamykający tekst Małgorzaty Rosalskiej pokazuje dynamikę rozwoju katolickich uniwersytetów w ostatnim ćwierćwieczu w perspektywie historycznej i w kontekście zmian organizacyjnych i programowych. Autorka stwierdza, że „W Polsce kiedy tradycyjna formuła funkcjonowania tych placówek przestała być adekwatna do wyzwań związanych z przemianami społecznymi i ekonomicznymi, nikt nie podjął się próby reformy lub adaptacji katolickich uniwersytetów do nowych czasów" (s. 148). Postępująca anomia tego typu placówek skłania do pytania, czy to jest stan już nieodwracalny, czy może tymczasowy.

\section{Uniwersytet ludowy - idee, koncepcje i rozwiązania praktyczne}

W części trzeciej, najobszerniejszej, znajduje czytelnik sześć szkiców, dotyczących zarówno samej idei uniwersytetu ludowego i jego koncepcji pracy, jak również przykłady ich realizacji w praktyce. Ową cześć otwiera tekst Piotra Kowzana, który rekonstruuje światopogląd Mikołaja Grundtviga na podstawie przetłumaczonych na język polski tekstów. Następnie Lucjan Turos opisuje Zofię Solarzową, wielką indywidualność, nauczycielkę w uniwersytetach ludowych w Szycach i Gaci Przeworskiej, działaczkę ruchu ludowego, autorkę oryginalnej koncepcji wychowania estetycznego, realizowany przez „teatr z głowy” (s. 191), której istotą jest wiara w twórcze możliwości czło- 
wieka i przekonanie o jego silnej potrzebie wyrażania siebie, swoich potrzeb, doświadczeń i ideałów. Iwona Błaszczak w swoim tekście, który doskonale koresponduje z dwoma wcześniejszymi, przybliża czytelnikowi postać Feliksa Popławskiega, a dokładniej jego koncepcję uniwersytetu ludowego, „mającą charakter koncepcji demokratycznej egalitaryzacji ról społecznych młodego pokolenia wsi”. Oprócz tradycyjnych ról żywiciela i obrońcy poszerzył ją o partnerską rolę gospodarza ziemi polskiej oraz współtwórcy wartości kultury narodowej (s. 233). Tekst ten można odczytać jako apel o odbudowanie wizerunku współczesnego humanisty, który ma być wyznawcą wiary w dobroć i piękno drugiego człowieka. Natomiast Maria Radziszewska, podejmując się zadania opisu specyfiki uniwersytetów ludowych na Warmii i mazurach w PRL, ukazuje sens idei owych placówek, które miałby być dostosowane do społecznych warunków i objąć troską każdą grupę ludności, zarówno nowych osadników, przesiedleńców, jak i ludność rodzimą. Jest to o tyle ważny tekst, że pokazuje sedno edukacji włączającej, z którą współcześnie mamy niemałe kłopoty. O uniwersytecie ludowym w Wierzchosławicach Janusz Skicki napisał, że jest to jedna z najwspanialszych instytucji służących krzewieniu nauki i kultury wiejskiej położonych w powicie tarnowskim (s. 270). Autor z wielką skrupulatnością historyka ukazuje czytelnikowi wielość faktów pozwalających zrozumieć wyjątkowość tego uniwersytetu ludowego. Tekst Zofii Kaczor-Jędrzyckiej przedstawia, parafrazując Milana Kunderę, „mądrość powieści” uniwersytetów ludowych i tego, że może stać się szansą na miejsce, także te wirtualne, odbudowy świata wartości.

\section{Uniwersytet ludowy w polskich czasopismach pedagogicznych}

W tej części widzimy, że redaktorzy zdecydowali się wydzielić trzy teksty, które odnoszą się do analiz problematyki uniwersytetów ludowych w polskim piśmiennictwie pedagogicznym. Dwa z nich, Teresy Gomuły i Eleonory Sapii-Drewniak, dotyczą analizy czasopism, w których odnajdujemy studia nad uniwersytetami ludowymi. tj. dwóch miesięczników edukacji dorosłych przedwojennej „Pracy Oświatowej” oraz powojennej „Oświaty Dorosłych”. Szersze spektrum popularyzacji działalności uniwersytetów ludowych w czasopismach i innych publikacjach w dwudziestolecia międzywojennego przedstawia Jan Wnęk. Z tych trzech tekstów wynika, jak dużą wartość (w ówczesnych czasach) miały uniwersytety ludowe dla życia społecznego. 


\section{Z ziemi pomorskiej}

W piątej części znajdzie czytelnik rozważania Cezarego Obrachta-Prondzyńskiego na temat edukacyjnych kontekstów wynikających z dziedzictwa kulturowego wsi pomorskiej, tak ważnych w pracy Kaszubskiego Uniwersytetu Ludowego. Autor stawia bardzo wartościowe pytanie: „na ile dziedzictwo kulturowe wsi pomorskiej może być kapitałem kulturowym, który da się wykorzystać w rozwijaniu współczesnego życia na wsi?” (s. 379). Następnie Paweł Śpica dokonuje analizy działań Hufców Wiejskich Powszechnej Organizacji „Służba Polsce”, która po 1948 roku przyjmowała młodzież m.in. z zamykanych wówczas uniwersytetów ludowych, które zdaniem autora dążyły do indoktrynacji politycznej młodzieży, natomiast spełniane przez nie zadania w zakresie edukacji stanowiły jedynie przykrywkę dla rzeczywistej intencji władz komunistycznych (s. 296). To też może świadczyć o tym, że uniwersytety ludowe zamykano również dlatego, że były szkołami wolnościowymi a nie ideologicznymi. Tekst Marka Byczkowskiego, dyrektor, Kaszubskiego Uniwersytetu Ludowego w Wieżycy, zamyka recenzowaną monografię. Autor wyraża głęboką troskę o przyszłość tych placówek na polskim (i nie tylko) gruncie, która nie jest bezpodstawna, ponieważ na dzień dzisiejszy decydenci zamykają placówki oświatowe z czysto ekonomicznych przesłanek, nie chcąc zauważyć długofalowych efektów całożyciowego kształcenia.

\section{Zakończenie}

Warto obserwować dalsze losy uniwersytetów ludowych w Polsce. Uniwersytet ludowy jest bowiem demokratycznie urządzoną społecznością uczących się, która daje szansę na rozwój - zarówno w sferze osobistej, jak i społecznej, pozwala mądrze zagospodarować czas i elastycznie dobierać formy realizacji różnorodnych zamierzeń, zachęca wspólnotę do współtworzenia programu. Te cechy sprawiają, że uniwersytet ludowy, będąc ciekawą alternatywą dla innych ofert edukacyjnych, może stać się ponownie instytucją społecznie rozpoznawalną i ważną. Warto więc w gronie teoretyków i praktyków edukacji dorosłych zastanowić się, w jaki sposób można szarzej propagować sposób myślenia o edukacji zaproponowany przez Grundtviga. „Każdy człowiek może swój sens życia wyprowadzić tylko ze swojej własnej indywidualności tzn. z tych cech i właściwości, które są tylko jego, które decydują o jego tożsamości i są jego podstawą odniesienia do spraw świata rzeczy, ludzi, przyrody i wartości" (Szczepański 1986, s. 237). Warto na zakończenie zadać pytanie: w jakim stopniu współcześnie kształcenie jest 
wartością uznawaną za autonomiczną (możliwość samorealizacji), w jakim zaś za instrumentalną (możliwość awansu, odejście od ciężkiej pracy)? Jest to bowiem dobro powszechnie pożądane, stanowiące podstawę do osiągnięcia wielu wartości ważnych dla zdobycia i poczucia sukcesu życiowego (Borowicz 1983, s. 3).

Maciej Jabłoński

\section{Bibliografia}

Borowicz R. (1983), Zakres i mechanizmy selekcji w szkole, PWN, Warszawa.

Byczkowski M., Maliszewski T., Przybylska E. (red.) (2003), Uniwersytet ludowy szkoła dla życia, Wydawnictwo Diecezji Pelplińskiej „Bernardinum”, Wieżyca. Habermas J. (2000), Filozoficzny dyskurs nowoczesności, Uniwersitas, Kraków.

Komeński J. A., (1956), Wielka dydaktyka, PAN, Wrocław.

Półturzycki J., (1994), Uniwersytet powszechny, „Edukacja Dorosłych”, nr 3/1994.

Schindler N., (2002), Ludzie prości, ludzie niepokorni..., Wiedza Powszechna, Warszawa.

Solarczyk H., (2004), Pozaszkolna edukacja obywatelska (polityczna) młodzieży i dorostych, „Rocznik Andragogiczny”.

Turos L., (1999), Andragogika ogólna, Wydawnictwo „Żak”, Warszawa. 